Journal Home Page:

http://perlinguam.journals.ac.za

\section{Per ${ }_{\text {Linguam }}$}

A Journal for Language Learning Tydskrif vir Taalaanleer

\title{
SECURING THE FORT: CAPTURING READING PEDAGOGY IN THE FOUNDATION PHASE
}

\author{
K Steinke \\ University of Mpumalanga \\ R Wildsmith-Cromarty \\ North-West University
}

\begin{abstract}
The focus of this paper is on an instrument known as the Facilitative Orientation to Reading Teaching, or FORT, that was designed to capture how teachers' pedagogical content knowledge (PCK) can influence literacy acquisition at Foundation Phase level. The FORT can capture the 'what' and 'how often' of classroom practice and, when combined with qualitative data, it can provide the 'why' and also ascertain whether what teachers say they do when they teach is in accordance with their actual classroom practice. The effectiveness of the instrument will be explained via specific findings from a multiple-case study undertaken with Grade 3 and 4 learners between 2015 and 2017 at two schools in the Midlands area of KwaZulu-Natal. The study involved a total of eight teachers and their classes, while the researchers recorded a total of 34 lessons, most of which were taught in English and some in isiZulu, with class sizes ranging between 35 and 45 learners. Findings indicate that additional training alone may be insufficient to change embedded top-down and teacher-led teaching styles and that teachers may benefit more from on-going support and mentoring such as coaching.
\end{abstract}

Keywords:Literacy; Reading Teaching; Pedagogy; Foundation Phase; Intermediate Phase; PCK

\section{INTRODUCTION}

This paper will focus on a classroom observation instrument designed to capture classroom reading pedagogy data and how it was used in a study of reading teaching practice across Grade 3 and 4. The study was conducted in the Midlands area of KwaZulu-Natal between 2015 and 2017 and its aim was to enhance literacy skills acquisition at the foundation and intermediate school levels. The instrument is called the Facilitative Orientation to Reading Teaching, or FORT and was based on original instruments such as the Communicative Orientation of Language Teaching (COLT) Observation Scheme (Spada and Fröhlich, 1995, Wildsmith, 1992) and the system for measuring classification and framing in teaching in early grade classrooms (Hoadley, 2005). While it provides mainly quantitative data based on frequency of practices, it also contains qualitative categories and can be used to capture classroom events and discourse. The purpose of the FORT was to capture classroom practice in a natural, teaching environment in order to answer the following four research questions: 
1. What do teachers do when they teach reading?

2. Which practices are they using to encourage literacy acquisition and which practices hinder the process?

3. Do teachers teach as they believe they do?

4. Does additional teacher-training in reading teaching assist teachers to become more effective in literacy teaching?

Past research has highlighted the correlation between reading skills and academic success yet there continues to be an under-emphasis on the development of reading skills at the earlier grade levels in South Africa (Pretorius, 2015, Pretorius and Klapwijk, 2016). This lack of development contributes to the high drop-out rate in both formal school and tertiary institutions (Klapwijk, 2015, Steinke, 2012). This study is unique in that, although participant observation research has been carried out in foundation and intermediate grades in South Africa, there is, to date, no specific study of reading teaching and PCK across Grade 3 and 4, despite recommendations that this be carried out (Mkhize, 2013). In addition, this study made use of video-recorded lessons that allowed the observers repeated viewings and nuanced observations. The data captured from the video recordings weres recorded on the FORT and provided detailed, layered analyses of teacher practices and learner responses in the classroom. This allowed for triangulation from the teacher interviews in order to compare teachers' beliefs with their practices.

\section{READING TEACHING}

Despite the curriculum's (CAPS) emphasis on communicative approaches for language and literacy teaching, rote learning continues to be used in South African classrooms. This often results in learners who end up only able to 'bark at print' (Pretorius, 2002: 92). The reasons are varied but include a lack of concern for meaning or comprehension (Pretorius, 2002, Klapwijk, 2015); a lack of effective teacher training (Ramadiro, 2014, Taylor, 2002); OBE failure (Jansen, 1998, Reeves and Muller, 2005); and language issues (Henning, 2012, Wildsmith-Cromarty, 1997). Despite the recent curriculum revision as instituted by the Revised National Curriculum Statement (RNCS) (Chisholm, 2004, Vandeyar and Killen, 2003) and the Curriculum and Assessment Policy Statements (CAPS) (Department of Basic Education, 2011, Govender and Hugo, 2018) learners continue to struggle with literacy in both their mother-tongue and English (Letseka, 2014, Mather and Land, 2014). Reading can be regarded as a multifaceted process that involves word recognition, comprehension, fluency and motivation that readers integrate to make meaning from print (Van Staden and Zimmerman, 2017). Although meaningful comprehension is the primary goal of reading from the beginning, teachers still tend to focus on phonics or decoding to the detriment of comprehension as they do not perceive reading as a meaningful process (Verbeek, 2010). Decoding is the process whereby print is translated into speech by matching letters to sounds and recognising letter patterns, such as syllables and words. The ability to rapidly decode printed texts into meaningful language units is critical for reaching the ultimate goal of reading, which is comprehension (Wang et al., 2018). In contrast, comprehension is the ability to make meaning from written texts and results from an interaction between reader, text, context and reading strategies the reader brings to the text (Edwards and Turner, 2009). 
Various South African studies report the difficulties that teachers face when trying to teach reading, resulting in learners unable to read. Verbeek (2010) identifies a number of challenges, ranging from a lack of PCK accompanied by a lack of assessment; a lack of understanding on the part of teachers as to the different components of reading and how literacy develops and an almost exclusive reliance on phonics and decoding because of a perception that reading is not a meaningful process. Other studies have found no encouragement of reading in the home language as English had priority and a lack of reading resources in the home languages (Nkosi, 2011); low levels of skill which are essential for comprehension in the individual reading components such as phonological awareness, oral fluency and vocabulary acquisition amongst learners (Draper and Spaull, 2015, Venter, 2012) and a lack of understanding of how to use strategies, plan reading comprehension or read for meaning (Mudzielwana, 2012). In a survey on teachers' attitudes and beliefs regarding reading comprehension, Pretorius \& Klapwijk (2016) found that while teachers at state schools felt that their learners struggled to read, this did not appear to take precedence as a teaching focus in the classrooms. In addition, teachers in the lower quintile schools (1 to 3 ) seemed to read less and own fewer books than teachers in the higher quintiles (4 to 5). This points to the need for teachers to be skilled readers themselves so that they can develop strong literacy habits in their learners. Recommendations were made to include explicit reading instruction strategies in teacher-training courses. The researchers also argue for effective comprehension intervention programmes in South African classrooms.

Further studies looking at reading pedagogy include Hoadley's (2017) analysis of the pedagogy of eight teachers in the context of the CAPS curriculum reform. The teachers were observed teaching Mathematics, Home Language and First Additional Language and were assumed to have an 'ideal' pedagogy based on Bernstein's system of classification and framing (Hoadley, 2005a). Findings showed no correlation between 'good' teaching and student achievement, which points to a lack of transfer of training in the classroom and the need for some type of intervention in helping teachers teach their learners to read (Hoadley, 2017).

The Early Grade Reading Study (EGRS) (Taylor et al., 2017) introduced three intervention models at Grade $1-3$ level in order to improve reading outcomes in the learners' home language, Setswana. The project took place at 230 schools in the North West Province and the research consisted of classroom observation and eight case studies. A Randomised Control Trial (RCT) was used to conduct a formal impact evaluation of the interventions. The first intervention consisted of a structured learning programme and centralised training for teachers consisting of CAPS- aligned lesson plans, reading materials and training at workshops biannually. The second intervention was a structured learning programme with on-site coaching. Finally, there was a parental intervention to improve learners' home support. The interventions assisted large classes and mid- to upper-range learners in urban schools the most. However, the impact of teaching approaches was greater for those who received coaching and ongoing support than for those who received training only (Taylor et al., 2017).

The truth is that learners who do not learn to read by the end of Grade 3 are set up for academic failure and are not likely to catch up (Ngema, 2011, Pretorius and Mampuru, 2007) The teacher is vital in this learning process (Wildsmith-Cromarty, 2012) especially her pedagogical content knowledge or PCK. Pryor et al (2012) found that initial teacher education has the strongest impact on trainee teachers but tends to produce teacher-led approaches with little variation or 
flexibility, as it tended to follow the patterns originally set in the colleges. In addition, readingteaching training was focused more on learning subject content than on teaching methods. This resulted in a serious lack of PCK. Teachers lacked the agency to adapt what they had been taught in the colleges to their particular country's needs and challenges. PCK incorporates the subject content knowledge and the pedagogical knowledge of how best to put this across to learners (Schulman, 1987), i.e. if subject content knowledge forms the 'what' of teaching, then PCK forms the 'how'. Teachers must be able to take what they know and transform it so that learning becomes available and comprehensible to their learners. In a discussion of the creation of resource books for teachers to enable them to enhance their own understanding of subject content, Wildsmith-Cromarty (2012) points out that the teachers were unable to use the resource books to mediate the information it contained via activities or tasks in the classroom because of their limited understanding of PCK. Akyeampong et al (2013) also found that reading teaching formed only a small section of the college curriculum and did not prepare teachers adequately for teaching literacy and numeracy in the early grades. The inherent principles contained within a methodology or approach can assist the learning process if the teacher is principled in his/her choice of teaching tools and knowledge (Gambrell et al., 2011). It was this aspect of PCK that the current study examined, which was the reason for the use of classroom observation with accompanying video recordings as research tools. Teachers may believe they teach a certain way, but what do they actually do when they teach? The study thus investigated teachers' PCK and reading teaching across Grade 3 and 4 (Mkhize, 2013), in order to gauge the extent to which teachers moved from decoding to comprehension and how they did it. The FORT instrument was developed for the purpose of capturing classroom reading teaching practice. A discussion of the context of the research follows.

\section{METHODOLOGY}

The research was conducted at two primary schools within a $5 \mathrm{~km}$ radius of each other in the KwaZulu-Natal Midlands between April 2016 and June 2017. School 1 (SE) uses English as LoLT from Grade R, whilst School 2 (SZ) uses isiZulu from Grade R until the end of Grade 3 and then switches to English from Grade 4. Although SE is designated as Quintile 4 while SZ is Quintile 2, learners from both schools originate mainly from the local informal settlements. A total of eight teachers (T1 to T8) teaching Grade 3 and 4, participated. The focus of the research was on how teachers teach reading. The research instruments, including FORT categories, were informed by current, evidence-based best reading teaching practice, such as scaffolding; the 'hidden curriculum' and pedagogic discourse; functional grammar; the importance of effective writing in context; the value of teacher talk and explicit reading teaching (Bernstein, 1990, Halliday, 1994, Martin, 1999, Rose, 2005, Tough, 1977, Vygotsky, 1978). FORT categories were also based on the CAPS specified outcomes for Grade 3 and 4 learners, including the integration of language elements into the teaching of reading, such as punctuation, grammar and spelling; types of reading; decoding and comprehension; open and closed questions; and vocabulary (Department of Basic Education, 2011b).

While all Government school teachers must use CAPS, four of the teachers used additional reading approaches (either Read to Learn (R2L) or READ) in addition to CAPS. Both R2L and READ follow a social constructivist approach based on the ideas of Vygotsky (1978) that understand reading as a social practice. Included in this is the idea of scaffolding where both 
top-down (meaning) and bottom-up (decoding) strategies are used. Decoding consists of sounds, blends and syllables, whereas comprehension means that the learner must construct the meaning of a text based on his prior knowledge (Yang and Wilson, 2006). During scaffolding, a teacher needs to set up a task which encourages learners to go beyond their current capacity whilst providing the support they need to achieve this. As they become more proficient, the scaffolding is withdrawn so that they can perform the task on their own (Yang \& Wilson, 2006). R2L holds explicit teaching as a central component (Rose and Martin, 2012). READ, however, is based upon natural approaches which do not encourage explicit teaching, leaving learners to discover reading and writing for themselves. Such approaches may be insufficient for disadvantaged learners (Rose, 2005). For effective literacy acquisition, children need explicit instruction and cannot be expected to independently discover the rules of written language by themselves (Nazaryan, 2014). The research in question also investigated whether the additional exposure to reading courses for four of the teachers had an influence on their own teaching of reading, i.e. their PCK.

\section{RESEARCH DESIGN}

The study adopted a mixed-methods approach following a parallel-convergent design (Teddlie and Tashakkori, 2009). In addition, it was a multiple, explanatory case study (Yin, 2013). A 'Restrictive-Facilitative' theoretical model was developed for the study which informed the development of the FORT and takes into consideration traditional teaching approaches (Bloom and Krathwohl, 1966, Skinner, 1954); communicative approaches (Dewey, 1902, Freire, 1972) and what the researchers have named the 'emancipatory approach' (Bernstein, 1990; Halliday, 1994; Rose \& Martin, 2012; Vygotsky, 1978).

\section{DATA COLLECTION}

Data collection at both sites consisted of classroom observation and video recordings of language and reading lessons in both Grade 3 and 4 classrooms. Videotaping the lessons allowed for review by the researchers for accuracy and inter-rater reliability, thus increasing validity (Creswell, 2011). A total of 34 lessons were recorded overall. The researchers aimed to visit each school on average once a week during the data collection period, dependent on the availability of access. The resulting FORT data were designed to answer research questions one and two, namely what teachers do when they teach and whether their practices help or hinder learning. In addition, participating teachers were interviewed to ascertain their views, attitudes and underlying theories behind their teaching practice (see Appendix B). Personal observations by the researchers were also recorded which were followed up with semi-formal and informal interviews with the participating teachers, once the initial data had been analysed. This was a form of member checking. The qualitative data obtained from the various interviews and observations were placed alongside the data from the FORT to ascertain whether teachers' perceptions of how they teach was borne out from their teaching practice in the classroom, thereby addressing the third research question. Question four was addressed by grouping the teachers into additionally trained (A) and non-additionally trained (NA) and then re-analysing the FORT data to look for similarities and differences in patterns or trends.

\section{DATA ANALYSIS}

Per Linguam 2019 35(3):29-58

http://dx.doi.org/10.5785/35-3-806 
The classroom lessons were analysed individually before being grouped according to teachers who had experienced additional specialised reading training and those who had not. Each teacher and his/her? classroom formed one case study. The groups were equally divided into four teachers each which allowed for a comparative analysis of the teachers practices in the classroom, i.e. whether teachers in the additional training group taught more effectively in making use of more 'best practice' strategies according to the FORT categories. All videorecorded data was captured on the FORT instrument (see Appendix A). Each lesson was 20 minutes long and were captured across a 5-minute time measurement in order to gauge in detail how often an activity or event occurred. Once the total number of events was recorded, an average was taken across the relevant number of lessons for each teacher and entered onto a spreadsheet from which a data set for each teacher was compiled. In addition, pre- and postreading level assessments of all participating learners were taken, at both Grade 3 and 4 levels, to ascertain initial reading levels and also to assess the amount of growth in literacy skills across the data collection period, if any. However, the results from these reading assessments are not dealt with in this paper. The FORT is divided into two sections: Part A contains PCK and Reading Teaching as well as Management, while Part B contains Classroom Interaction from teacher to student and from student to teacher. Each section was sub-divided into levels of separate categories, outlined below.

The FORT sub-categories in Part A include the choice of activity and materials, participant organisation, modality, comprehension, and activating old or presenting new knowledge. Under these sub-categories, further teaching practices that focus on the use of integrated skills and forms of reading are included. These include activating old and presenting new knowledge; open and closed questions; inferential and referential comprehension; phonemic awareness; familiar word recognition; non-word reading; oral fluency; group and individual reading aloud; group and individual silent reading; writing; vocabulary; grammar; punctuation; spelling and individual and group response types (Appendix A). Under Management, the sub-categories include classroom procedure; discipline; pacing and sequencing of the curriculum; teacher prompts; and discourse markers. Part B consists of the language of learning and teaching and the dialogue that occurs during the classroom interactions. The interactions occur for both teacher to student interaction and for student to teacher interaction. The dialogue is divided into a selection of discourse events, each of which is evidenced as facilitative practice. These include code-switching; requesting; feedback; evaluation question; correction; repetition; instruction; paraphrase; explanation; clarification; elaboration; response to cue; affirmation; recast; emotional response; responds to difficulties; and other.

A graphic presentation and discussion of the study findings follow. The data provided in the graphs represent analyses of the A (additionally-trained) and NA (non-additionally trained) groups respectively. Each graph is followed by a discussion of the results in terms of whether the represented practices of the teachers are facilitative or restrictive. Selected quotes from participating teacher interviews are included in the discussion in order to show how the FORT data either support, or do not support, the perception of teachers as to how they teach.

\section{FINDINGS}


As mentioned, the FORT consists of two parts. Figure 1 shows Part A: Reading Teaching and PCK. The values are placed according to the FORT sub-categories, which will each be discussed separately.

\section{Figure 1: Reading teaching and PCK}

\section{Figure 1: Reading Teaching \& PCK}

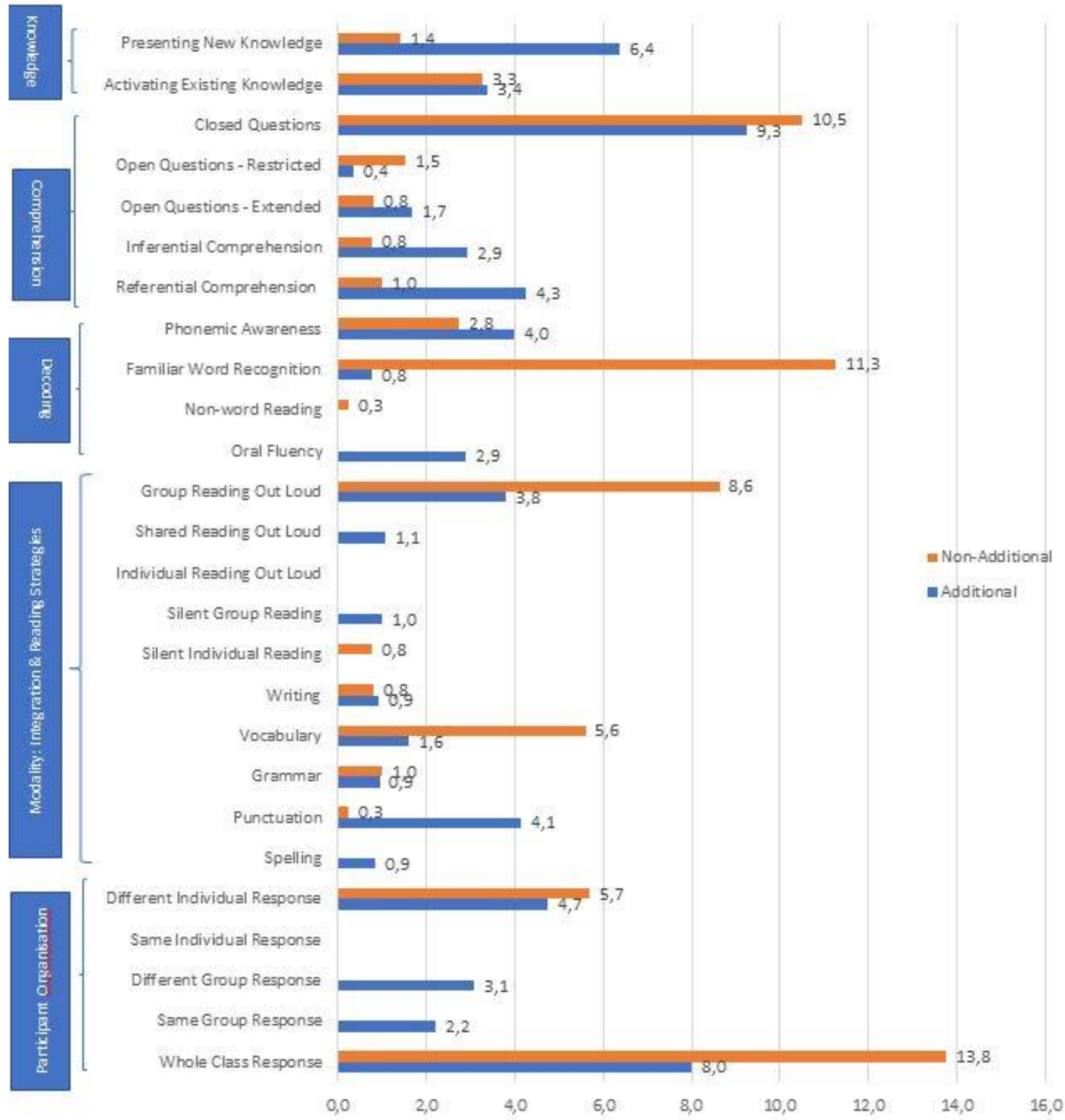

\section{Activating Existing and Presenting New Knowledge}

Knowledge consists of either activating the existing knowledge of learners and/or presenting new knowledge. Learners who can integrate existing knowledge with new information are able to construct meaning more easily than those who cannot and thus progress through the curriculum 
more effectively (Rose, 2015, Strangman et al., 2010, Xie, 2017). Both groups make use of activating existing knowledge at almost identical rates, although these are very low (3.3 and 3.4). The A teachers present new knowledge at a far higher rate. The reason for this may be that the teachers in the A group were using a scaffolded form of teaching (mainly Read to Learn) where the creation of new cognitive references is key. During the interviews, all teachers expressed their belief that it is important to make use of both types of knowledge, for example: '(This is) very important. I use flashcards and pictures to activate background knowledge and create new (information) in the classroom environment. Connections are built in this way.' (T5 -SZ). Here is a prime example of a mismatch between teachers' beliefs and their practices. The very low rates of activating existing knowledge to create a frame of reference for learners challenge the above statement.

\section{Comprehension}

The first category for comprehension is open versus closed questions. Scores were higher for closed questions for both groups with NAs slightly higher. This is consistent with a restrictive type of pedagogy as a closed question requires a simple 'yes' or 'no' answer. Open questions on the other hand require thinking or reflection. Open questions are important in teaching at early grade levels for the cognitive development of learners (Henning, 2012). However, not all open questions are equally 'valuable' (Leech and Onwuegbuzie, 2007). For example, the FORT has two types of open questions: extended and restricted. Extended open questions allow for reflection and creativity on the part of the learners and also include the 'Focus' questions that are used in the R2L scaffolded reading cycle, as these are meant to guide the learner and include opportunities for both learner and teacher to elaborate on responses and extend learning (Rose \& Martin, 2012). On the other hand, restricted open questions call for simpler, retrieval-type responses. The NA group is higher on the restricted open questions. On the other hand, the As score higher on the extended open questions. As creative open questions can benefit learners' critical thinking and cognitive skills (Yusoff and Seman, 2018), their use is facilitative in helping learners to achieve the higher-order comprehension outcomes required by CAPS (Department of Basic Education, 2011).

With reference to inferential and referential comprehension, the data shows that A teachers score slightly higher on both types. The low rate of comprehension used by the NAs could be seen as restrictive, considering that the goal of reading is defined as the ability to read for meaning (Pretorius and Klapwijk, 2016). Encouraging learners to ask questions about what they are reading is a more effective way of enhancing comprehension than teacher-led questioning. 


\section{Decoding}

Although comprehension is paramount, decoding remains an important component of reading. Decoding also involves phonemic awareness; oral reading fluency; vocabulary; familiar word reading; and non-word reading (Ehri, 2011, Phonic Books Ltd, 2011). The A group scores slightly higher for phonemic awareness and is the only group to make use of oral fluency, which can be seen as facilitative. In contrast, only the NAs use non-word reading, which, in itself, can be facilitative as it helps learners link sounds to letters. They can be an effective way for teachers to check gaps in learners' knowledge of phonics and the efficiency of their blending skills (Catts, 2017, Stanley et al., 2018).

The familiar word recognition score is high for the NAs. However, only four lessons were recorded on average for the teachers and one cannot make generalisations from such a small sample as to their entire teaching repertoire. Rather, the lessons allow the researchers a 'snapshot' into the various teaching styles of the teachers. All the teachers who made high use of familiar word recognition made word lists on the board and asked learners to read and re-read the word-list out loud, many times over. This can also be seen as vocabulary building. Although vocabulary learning is extremely important for reading, it is recognised that memorisation and repetition alone are not necessarily the most effective way to learn new words. More modern methods can be used, such as reading about a wide range of topics and using visual aids or objects, which would create a more facilitative learning environment (Alqahtani, 2015, Boyer, 2017).

Oral reading fluency remains one of the most predictable and reliable indicators of learner comprehension (Reschly et al., 2009). Oral fluency can be described as a learner reading a text with automaticity, speed and accuracy whilst being able to focus on the meaning. Only the A teachers use this category. In the recorded lessons, oral fluency events consisted of teachers holding up flash cards and/or breaking up words into syllables for pronunciation (which is also phonemic awareness), as well as sustained reading, where learners read and re-read extended text or a sentence (Hasbrouck and Tindal, 2006). Choral, or whole class, reading is also beneficial, not just for oral fluency but also to allow weaker students to follow along, whilst still hearing the text being read well with accuracy and pace (Hasbrouck \& Tindal, 2006). However, there was little individual reading, either out loud or silent, to balance out the whole class reading practice (see Modality below). What the FORT captures is that teaching styles can become entrenched and even those teachers who have had additional training tend to remain in a largely traditional teaching mode, bearing out the findings of the EGRS Report (Taylor et al., 2017). The implications for lack of change from a traditional teaching style are that reading teaching will continue to lack effectiveness (Richards and Rodgers, 2014).

\section{Modality}

Both groups made use of group reading out loud, with the NAs obtaining higher scores. Whilst the benefits of reading out loud are recognised (Polette, 2005), as with choral reading, it has its limitations. For example, it is difficult to monitor the individual learner's reading progress this way (Reutzel and Juth, 2017). Shared reading out loud is used by the A teachers only, while in the recorded lessons, no teachers in either group made use of individual reading out loud. Silent individual reading is used by A teachers only, whereas silent group reading is used by NA teachers only. The difference between the two reading modalities is in the teacher's Per Linguam 2019 35(3):29-58 http://dx.doi.org/10.5785/35-3-806 
organisation. For example, the learners may all go off to their own chosen spaces to read quietly for a while, or they may be required to read silently around the table as a group (Reutzel \& Juth, 2017). Silent reading is valuable in facilitating reading skills and there needs to be a focus on the learner reading silently for fluency without interruption from the teacher. However, such reading also needs careful monitoring from time to time to assess learner ability and/or progress (Jablonski, 2018). The lack or low rate of different reading modalities used by both groups could be seen as restrictive. Again, this is not to say that the differing forms of reading are not used by teachers in other, unrecorded lessons.

There is evidence that integrating language components into reading teaching is beneficial for increasing reading skills (Rose, 2018, Reed, 2012), provided the integration is done in a systematic and goal-oriented manner (Lyster, 1998). Only the A teachers made use of all the language categories. Writing and grammar are used by both groups at a similar rate, whereas spelling is used only by the A teachers. Punctuation is used at a high rate by the A teachers but hardly at all by the NAs. Vocabulary learning is used more by the NAs, which may be a reflection of all four of the NA teachers' beliefs that learners move from decoding to comprehension mainly via the use of vocabulary, word building, charts and visual aids placed on the classroom walls. As one teacher affirms: 'You work with vocabulary (learn new words together) and it flows together over time.' (T2 - SE)

\section{Participant Organisation}

The tables and chairs in the classrooms were arranged in such a way that the learners formed groups of approximately eight (8), which was the case for both schools. This was in accordance with the requirements of CAPS with the intention of allowing greater flexibility in response types from learners, whether individual or in a group. The pedagogical benefit of using varied types of responses from learners in the classroom is recognised (Rose, 2005). For example, when the teacher asks a question (in the recorded lessons), she selects a different individual each time to answer, or, in the case of group work, the teacher may choose different groups at their tables. Generally, the teachers tended not to select the same learner or group to answer a series of questions within the observed lesson. Both As and NAs made use of different individual responses, although the NAs were slightly higher. However, no teachers made use of same individual response. This may be because the classes were large, ranging from 35 to 49 learners and it is likely that the teachers chose to offer as many learners as possible a chance to answer questions. Only the A teachers made use of different group responses and same group responses. As these categories were used when learners were performing a task at their table as a group, this may indicate a higher rate of group work on the part of the A teachers, which would be facilitative. Both groups used a high rate of whole class or choral response, although the NAs were higher. It would appear that all teachers, whether additionally trained or not, ultimately resorted to choral responses. In addition, despite the scaffolding used by the A group, all the teachers tended to retain tight control. Although scaffolding is inherently designed to relax the sequencing and pacing boundaries by allowing weaker students to 'catch up', in these observed lessons there was no differentiation of task, or of allowing faster learners to work on other activities or individually (Logsdon, 2018). During the interviews, all the teachers expressed the importance not just of teacher-talk but of two-way interaction in the classroom, even though the actual data suggest that these are mainly teacher-led lessons (see Figure 2). Teacher 1 states in her interview that: 'They need to hear you saying things - they are learning the correct words Per Linguam 2019 35(3):29-58 http://dx.doi.org/10.5785/35-3-806 
(you are modelling them) and giving them extra knowledge. Interaction is two way - they give feedback as they learn.' (TI - SE). In the interviews, all teachers claimed to value group-work, while the FORT data indicate that they do not necessarily focus on it. As Teacher 3 puts it: 'This is very important as it improves communication both from student to student and from teacher to student. It helps students to teach each other.' (T3 - SE). This statement was certainly not evident in the data as most lessons were teacher-dominated.

In sum, the data for this part of the FORT showed evidence of high scores for closed questions, familiar word recognition, reading aloud in chorus and whole class responses, all of which point to tightly controlled, teacher-led lessons with very little reflection or deeper learning on the part of the learners. The following section and graphs show the data for the Management section of Part A of the FORT.

\section{FORT Part A: Management}

Classroom management involves the techniques teachers use to keep their classrooms organised, attentive and focused (Great Schools Partnership, 2017). Categories focus on prompts, discourse markers, pacing and sequencing, discipline and procedure. Verbal prompting allows the teacher to assess when learners are not moving at the required pace, when they are losing concentration or motivation (Government of Alberta: Education, 2017), whereas discourse markers in the teacher's speech indicate the organisation of learning material and time (Emmer and Stough, 2001). An understanding of sequencing and pacing of the curriculum in advantaging or disadvantaging certain learners is an important part of teacher management strategies (Margolis et al., 2001), as is discipline, or the ability to control the learning environment and respond to learners that may have behavioural problems. Finally, 'procedure' involves the teacher's knowledge of what needs to be done for effective teaching, such as handing out material and taking class registers (Cox, 2017). Figure 2 provides the Management data. 


\section{Figure 2: Management}

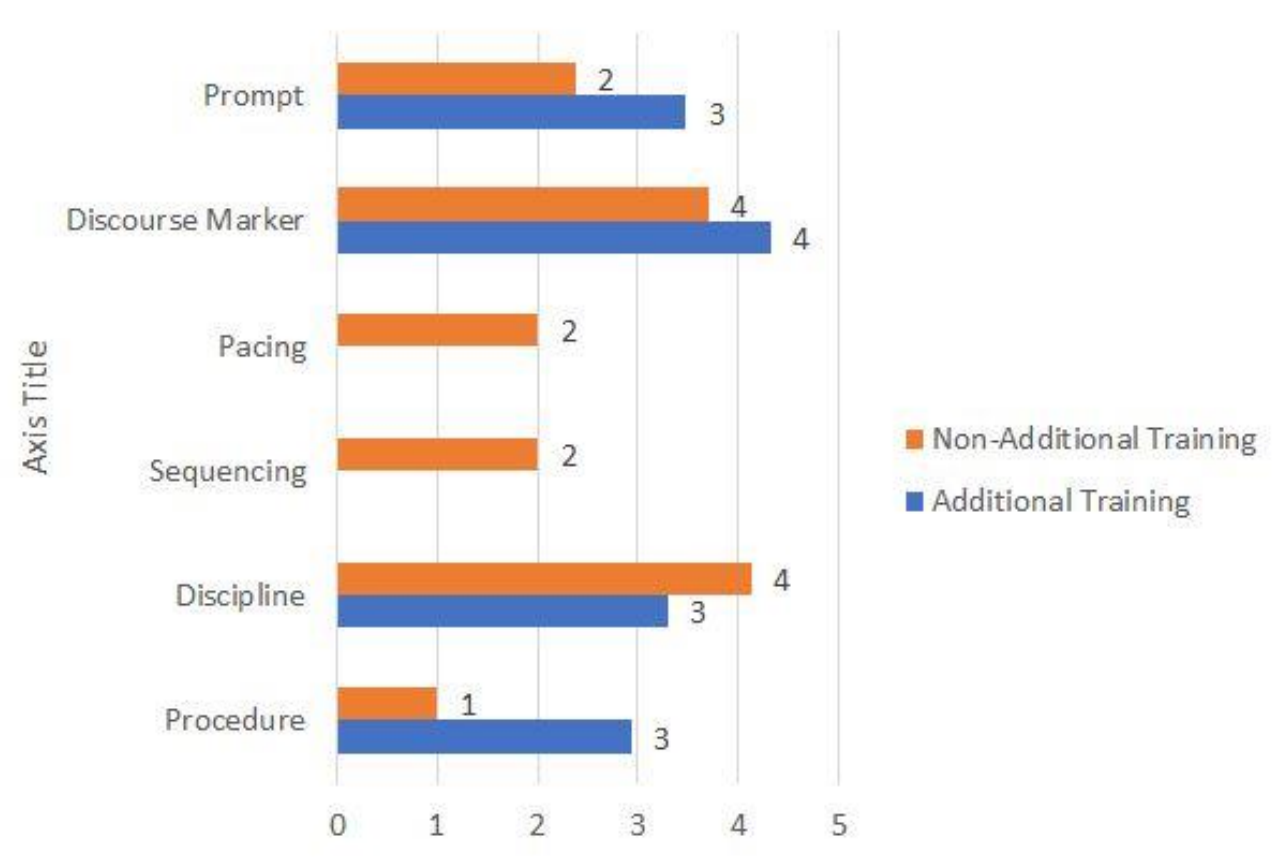

Figure 2: Management

\section{Management}

Figure 2 indicates that both teacher groups shared most of the Management categories at similar rates. In addition, observations showed that all the teachers tended to use both discipline, prompting and discourse markers in similar ways. For example, prompting was most often used to encourage readers to continue when they were reading or when the teacher had briefly halted the flow of the task to explain or clarify an issue. In the same way, all the teachers used discourse markers as a signal to mark-off sections of information. Each teacher had her own style and way of doing this (for example, she would use 'ok' or 'right' as discourse markers) but the function remained the same. Only the NA group made overt use of relaxing the sequencing and pacing of the curriculum. This data, however, is somewhat skewed by the fact that only one teacher out of the four in this group (T3 - SE), made use of this category as she perceived that the learners were not grasping a concept and deliberately returned to an earlier stage of the lesson. Even though the sequencing and pacing is not overtly indicated on the graph for the other teachers, those who used the scaffolded interaction cycle used it with the intention of relaxing the boundaries to cater for learners who may have fallen behind (Klapwijk, 2015). Thus, one must link the quantitative categories with the qualitative 'Activity \& Materials' category to obtain a more detailed picture, thereby also linking Parts A and B of the FORT. This provides not just the what but also the how and why of the pedagogy. It also supports the rationale behind selecting a mixed-methods design. Numbers alone are not sufficient (Leech \& Onwuegbuzie, 2007). The meaningfulness of the teacher style will depend on the related activity and theory (e.g. scaffolding via the R2L cycle) underlying her teaching. The activity and theory are guided by the PCK of a capable and skilled teacher and can extend learning (Rose \& Martin, 2012; Vygotsky, 1978). 
Another notable category from the data is Procedure. The use by the NAs was low, whereas its use by the As was slightly higher. The procedure data mainly consisted of teachers handing out worksheets, papers, or learners retrieving the relevant learning equipment. The higher rate of use of this category by the A group may be because of the increased activity levels used in the scaffolded learning cycle which involves additional materials such as sentence strips, scissors and chalk boards. Increased activity levels in the classroom would generally be seen as facilitative. The above has covered Part A of the FORT, Reading Teaching, PCK and Management. Below is the data for Part B that focuses on interaction patterns, firstly from student to teacher and then from teacher to student.

\section{FORT Part B: Student to teacher interaction}

Part B of the FORT contains categories of interaction that are beneficial to reading teaching. These include Code-switching, Requesting, Evaluation Questions, Feedback, Explanation, Elaboration, Affirmation, Correction, Repetition, Emotional Response and Other (Lovorn, 2008, Lyster, 1998, Nemours, 2017, Plüddemann, 2015). These discourse events not only assist with learner engagement but also with developing comprehension (Goeke, 2008, Hay et al., 2013). Figure 3 below contains the graphic data for student to teacher interaction. 
Figure 3: Student to Teacher Interaction

Figure 3: Student to Teacher Interaction

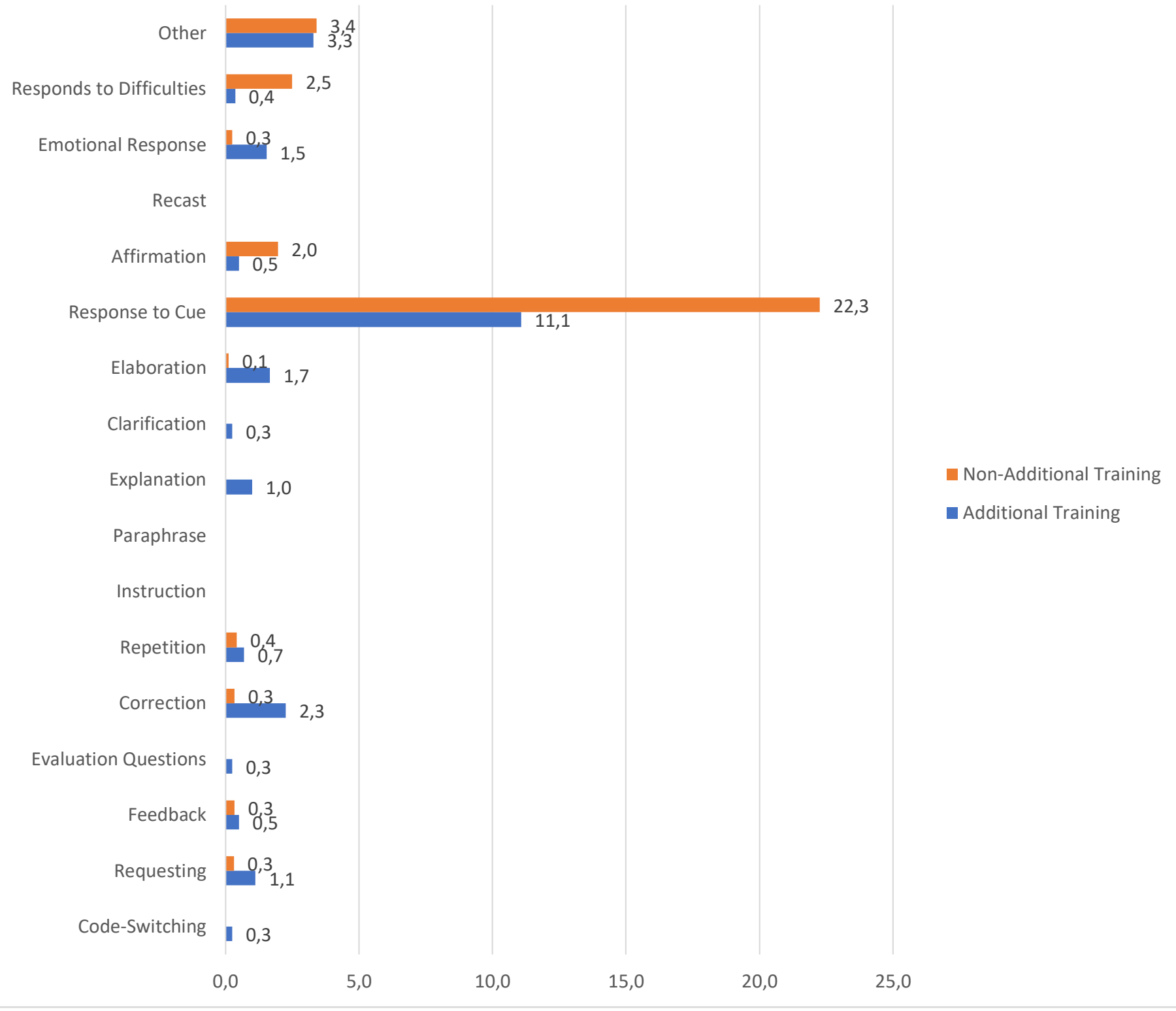

More of the categories in the above graph apply to A teachers, with 14 in total, compared to the NAs who had 11. As with Figure 1 (see Participant Organisation), from the overall low averages it is obvious that most of these lessons were teacher-led (Spaull \& Hoadley, 2017). The wide gap between scores for Response to Cue and the other categories could be due to the tight control over the lesson by the teacher who spent most of the time asking the learners closed questions. Although scaffolding is designed to elicit participation from learners, this does not preclude the fact that the continued lack of student participation and creative involvement in the lessons would be restrictive. Evidence shows that student interaction towards the teacher increases academic achievement, especially for weaker students, so lack of reciprocal interaction in the 
classroom would be restrictive (Casey, 2018). However, one must take into account the sizes of the classes both in this study (between 35 and 49 learners) and in South African Government schools as a whole. As class sizes increase, direct interactions with the teacher generally decreases (Taylor et al., 2017).

The data also indicate that both groups made use of Other at a similar rate. By 'Other' is meant non-verbal or emotional reactions from the learners, such as hand-clapping, going up to the front of the class to write on the board, performing tasks such as wiping their writing boards clean, raising their hands to answer questions or other physical movements. The use of 'Other' could point to greater learner involvement, which would generally be facilitative, for examplen a teacher asked learners to pretend to be a certain animal, such as a lion. Correlated with this are emotional responses, which the A teachers made use of at a slightly higher rate than the NAs. Emotional responses in this study mainly consisted of laughter and sometimes other forms of non-verbal communication such as pulling faces and showing surprise. This category is different from 'Affirmation', which has the function of supporting and encouraging learners' efforts (Martin and Rose, 2007). The learners responded at a greater rate to the NAs with affirmation. Correcting the teacher who pretended to have difficulties by producing the incorrect answer was a strategy teachers used to elicit learner engagement. The A teachers' learners scored higher in correcting the teacher, which indicates a similar pattern with a slightly different method of response from the learners. Both groups had a fairly low rate of learners elaborating on requests or answers in the lessons, although the As again scored higher than the NAs. Higher scores for the A teachers for categories that are more facilitative for learning to read could show increased awareness of the appropriate PCK for teaching reading. 'Elaborate' means that the learners are given an opportunity to expand on their initial answers to the teacher and most often involves different learners in a lesson putting forward differing answers, suggestions or solutions. Each 'elaboration session' was recorded as one event. In other words, not every answer from every learner was counted individually, but seen as one session and therefore, an elaboration.

Highlighted in Figure 3 are the responses to teachers' cues, with NAs scoring 22 and As scoring 11. The responses to cue consisted of direct responses to teacher-initiated interaction, often through questions, which indicates tighter control of the lesson. Learner participation assists in developing critical thinking skills as well as learning retention. However, this participation may be restricted due to class size as well as the hierarchal structures of teacher-led classrooms where the teacher traditionally holds the 'power' and makes the decisions (Weaver and Qi, 2005).

The final graph (Figure 4) contains the same categories as Figure 3, but this time it depicts Teacher-to-Student interactions. 
Figure 4: Teacher-to-Student interaction

Figure 4: Teacher to Student Interaction

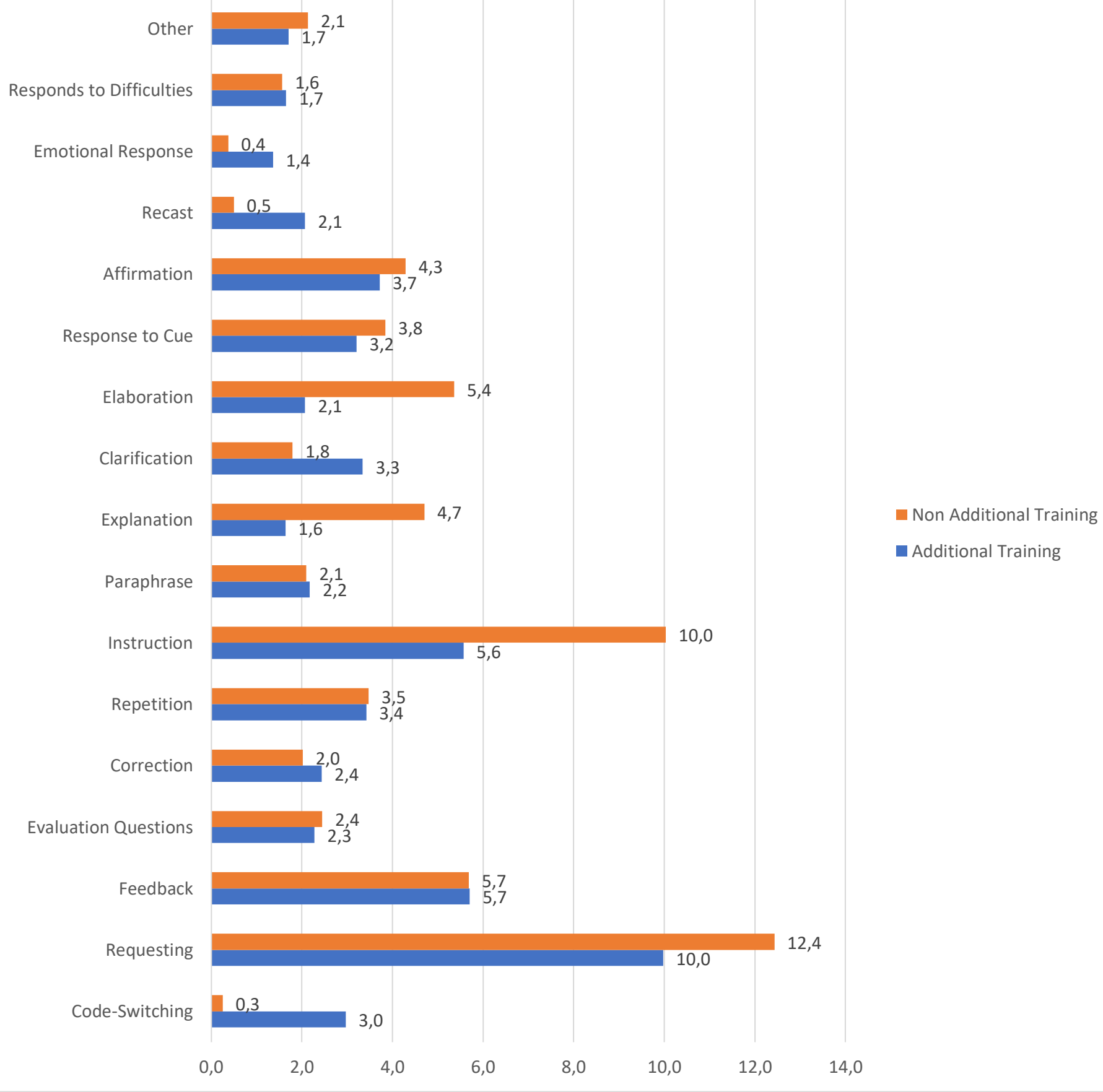

Figure 4 shows a high volume of teacher-to-student talk occurring in the classrooms, especially when compared to the student-to-teacher talk. The implications of this may be poorer outcomes 
for learners who do not actively participate in the classroom, as those involved in the learning process learn more effectively than those who do not.

The NAs had a considerably higher rate of elaboration, explanation and instruction than the A group. Elaboration is quite a meaningful and communicative category and involves instances where the teachers go into more detail on a topic or subject. This detail is often quite interesting and intended to extend the learners' understanding of an issue. For example, T3 (SE) may elaborate on why the Sun and the North Wind want a competition between themselves and how they are both very strong (a story from the CAPS workbook). Furthermore, T4 (SZ) may explain the past history of 'measurement' and how learners in the South African school system used to have to put their arm behind their head to determine if they were ready for school. These are, however, elaborations on the teachers' own initiatives. It does not necessarily indicate that the teacher encourages the learners to elaborate on their responses to her (see Figure 3) which would engage the learners in more meaningful participation. As mentioned, the NA teachers tended towards a more traditional, rote style of teaching (see Figure 3). This traditional style involves the use of mainly deductive reasoning, which may exclude inductive forms that require the students to think critically and discover concepts or answers for themselves (Anderson et al., 2018). As a consequence, teachers in the NA group may have used more elaboration, explanation and instruction as a form of 'banking', (Freire, 1972) or, in the paraphrased words of T4 (SZ) from the interview: 'the teacher talks, explains and the learners must 'do'. In this case, the 'over-use' of these discourse types would not be beneficial as the use of both deductive and inductive reasoning in teaching is more effective for learning than reliance on only one of them (Bowers and Kirby, 2010).

The NA teachers also scored slightly higher on the request category than the A teachers, and in return received more responses to their cues from the learners, which were mostly choral (see Figure 3). The As scored slightly higher in clarification, recasts and emotional responses, which tend to focus more on meaningful interaction, whilst they scored much higher than NAs in codeswitching. This might have been because two of the teachers in the NA group did not have isiZulu as their home language (and were, therefore, unlikely to be making use of it in the classroom). An examination of the functions of code-switching for the A group shows that it was used for the following purposes: explanation of concepts, translating words, communicating with a child who did not have isiZulu as his home language, instruction, correction, discipline, evaluation questions, and, in the case of T5, to indicate the transition from an isiZulu lesson to an English one with the same Grade 3 class. Only one of the remaining NAs, T6 (SZ), used codeswitching during the observed lessons for translating concepts from English to isiZulu. As the majority of learners in this study had isiZulu as their home language and yet had to learn in English (in SE from Grade R, in SZ, from Grade 4 onwards), the use of code-switching can be regarded as facilitative as its judicious use can assist learners to cope with the language barrier (Henning, 2012).

\section{CONCLUSION}

This paper has sought to explain how the FORT can capture the what and how often of classroom practice, as well as how can it can be combined with qualitative data from sources such as teacher semi-structured interviews and visual observations, to ascertain whether what teachers say they do when they teach is in accordance with their actual classroom practice. When Per Linguam 2019 35(3):29-58 http://dx.doi.org/10.5785/35-3-806 
combined with additional qualitative information, the FORT, with its quantitative and qualitative categories, is able to capture what happens in reading teaching at Foundation and Intermediate levels, as well as provide a picture of the how and why.

The analysis of the FORT data would seem to indicate that additional training in reading does make a difference to the effectiveness of reading teaching. Teachers have higher rates of extended open questions; greater integration of language elements with reading teaching and a higher focus on comprehension, whilst also making use of decoding categories such as oral fluency and phonemics. When the FORT data are placed alongside the data from the semistructured interviews, it shows that the A teachers also have a higher correlation between what they say and what they actually do when they teach, than the NA teachers. Whereas all teachers stated that group work is important for teaching and learning, only the As gave it greater focus in their classroom practice. The FORT data also indicate that teachers who actively make use of additional training in reading teaching appear to be more effective at extending learning, as they are making more use of best practice. The FORT has thus shown itself to be a nuanced, sensitive and reliable instrument that can accurately capture how teachers teach reading within a classroom setting.

However, the data also highlight several problem areas. For example, lack of learner participation with both $\mathrm{A}$ and NA teachers in the classroom is a concern. Both groups tend towards traditional, teacher-led teaching styles with choral responses from the learners. It appears that, although additional training is beneficial, it is not sufficient to transform teaching styles that are firmly and rigidly embedded (Hoadley, 2017). Research shows quite clearly that ineffective teacher training is a major contributor to the current literacy skills deficit of learners in South African schools and that CAPS is, by itself, insufficient to bridge the reading skills gap (Nehal, 2013, Pretorius et al., 2016). The teachers in this study, including those with additional training, may benefit from the Coaching model as outlined in the EGRS (Taylor et al., 2017), as it may take continuous exposure to new ideas and methods of teaching for teachers to be willing to consider using different strategies.

\section{REFERENCES}

ALQAHTANI, M. 2015. The importance of vocabulary in language learning and how to be taught. International Journal of Teaching and Education, 3, 21-34.

ANDERSON, C., MUELLER, E. \& SCHNEIDER, A. 2018. Heroically protecting our arguments: Using superheroes to teach inductive and deductive reasoning. Discourse: The Journal of the SCASD, 4, 68-74.

BERNSTEIN, B. 1990. The structuring of pedagogic discourse: Volume IV of Class, Codes and Control, London, Routledge.

BLOOM, B. \& KRATHWOHL, D. 1966. Taxonomy of educational objectives. Handbook I: Cognitive domain. British Journal of Educational Studies, 14, 119.

BOWERS, P. \& KIRBY, J. 2010. Effects of Morphological Instruction on Vocabulary Acquisition. An Interdisciplinary Journal, 23, 515-537.

BOYER, K. 2017. The relationship between vocabulary and reading comprehension in Third Grade students who are English language learners and reading below grade level. Master of Education, Goucher College. 
CASEY, C. 2018. Computer-Based Instruction as a form of differentiated instruction in a traditional, teacher-led, low-income, High School Biology classroom. Dissertations and Theses, Portland State University.

CATTS, H. 2017. Early identification of reading disabilities. In: CAIN, K., COMPTON, D. \& PARRILA, R. (eds.) Studies in Written Language and Literacy Theories of Reading Development. Amsterdam: John Benjamins Publishing.

CHISHOLM, L. 2004. The quality of primary education in South Africa. Background Paper Prepared for UNESCO Education for All Global Monitoring Report. UNESCO.

COX, J. 2017. Classroom management: Procedures. K-12 news, lessons \& shared resources by teachers, for teachers [Online]. Available: http://www.teachhub.com/classroommanagement-procedures [Accessed 5 March 2018].

CRESWELL, J. 2011. Controversies in mixed methods research. In: DENZIN, N. \& LINCOLN, Y. (eds.) The Sage Handbook of Qualitative Research. 4th ed. Thousand Oaks, C.A.: Sage.

DEPARTMENT OF BASIC EDUCATION, SOUTH AFRICA. 2011. Curriculum assessment policy statement Grades 4-6: English home language [Online]. Pretoria: Government Printing Works. Available: www.education.gov.za/Curriculum/NCSGradesR12/CAPS/tabid/420/Default.aspx [Accessed 7 March 2019].

DEWEY, J. 1902. The child and the curriculum, Southern Illinois University Press.

DRAPER, K. \& SPAULL, N. 2015. Examining oral reading fluency among Grade 5 rural English second language (ESL) learners in South Africa: An analysis of NNEDU 2013. South African Journal of Childhood Education, 5, 44-77.

EDWARDS, P. \& TURNER, J. 2009. Family literacy and reading comprehension, NY, Routledge.

EHRI, L. 2011. Grapheme-phoneme knowledge is essential for learning to read words in English. In: METSALA, J. \& EHRI, L. (eds.) Word Recognition in Beginning Literacy. N.Y.: Routledge.

EMMER, E. \& STOUGH, L. 2001. Classroom management: A critical part of educational psychology, with implications for teacher education. Educational Psychologist, 36, 103112.

FREIRE, P. 1972. Pedagogy of the oppressed, London, Penguin.

GAMBRELL, L., MALLOY, J. \& MAZZONI, S. 2011. Evidence-based best practices in comprehensive literacy instruction. In: MANDEL-MORROW, L. \& GAMBRELL, L. (eds.) Best Practices in Literacy Instruction. 4th ed. N.Y.: The Guilford Press.

GOEKE, J. 2008. Explicit instruction: Strategies for meaningful direct teaching, Harlow, Prentice Hall.

GOVENDER, R. \& HUGO, A. 2018. Educators' perceptions of the Foundation Phase English Home Language Curriculum and Assessment Policy Statement. Per Linguam, 34, 17-32.

GOVERNMENT OF ALBERTA: EDUCATION. 2017. Using cues or prompts: Teacher tip sheet [Online]. Alberta, C.A.: Government of Alberta. Available: http://www.learnalberta.ca/content/insp/html/teacher/usingcuesorprompts.pdf [Accessed 5th June 2017].

GREAT SCHOOLS PARTNERSHIP. 2017. Classroom management [Online]. Available: http://edglossary.org/classroom-management/ [Accessed 1 June 2017].

HALLIDAY, M. 1994. An introduction to functional grammar, London, Edward Arnold.

Per Linguam 2019 35(3):29-58

http://dx.doi.org/10.5785/35-3-806 
HASBROUCK, J. \& TINDAL, G. 2006. Oral reading fluency norms: A valuable assessment tool for reading teachers. The Reading Teacher, 59, 636-644.

HAY, J., MOLETSANE, M., NTOMBELA, S., PIENAAR, C., RAYMOND, E. \& STOFILE, S. 2013. Making inclusive education work in classrooms, Cape Town, Pearson.

HENNING, E. 2012. Learning concepts, language, and literacy in hybrid linguistic codes: The multilingual maze of urban Grade 1 classrooms in South Africa. Perspectives in Education, 30, 69-77.

HOADLEY, U. 2005. Social class, pedagogy and the specialization of voice in four South African primary schools. Unpublished PhD Thesis, University of Cape town.

HOADLEY, U. 2017. Learning to fly: Pedagogy in the Foundation Phase in the context of the CAPS reform. Journal of Education, 13-38.

JABLONSKI, K. 2018. Improving guided reading levels of 2 nd Grade students by implementing independent, silent reading. Degree of Master of Education, Goucher College.

JANSEN, J. 1998. Curriculum reform in South Africa: A critical analysis of outcomes based education. Cambridge Journal of Education, 28, pp. 321-332.

KLAPWIJK, N. 2015. EMC $^{2}=$ comprehension: A reading strategy instruction framework for all teachers. South African Journal of Education, 35, 1-10.

LEECH, N. \& ONWUEGBUZIE, A. 2007. An array of qualitative data analysis tools: A call for data analysis triangulation. School Psychology Quarterly, 22, 557.

LETSEKA, M. 2014. The illusion of education in South Africa. Procedia-Social and Behavioral Sciences, 116, 4864-4869.

LOGSDON, A. 2018. Pros and cons of differentiated teaching in school: Using multiple teaching styles to meet the needs of diverse students [Online]. Available: https://www.verywellfamily.com/differentiated-instruction-vs-traditional-methods2162351 [Accessed 5 September 2018].

LOVORN, M. 2008. Humor in the home and in the classroom: The benefits of laughing while we learn. Journal of Education and Human Development, 2, 1-12.

LYSTER, R. 1998. Recasts, repetition, and ambiguity in L2 classroom discourse. Studies in Second Language Acquisition, 20, 51-81.

MARGOLIS, E., SOLDATENKO, M., ACKER, S. \& GAIR, M. 2001. Hiding and outing the curriculum, NY, Routledge.

MARTIN, J. 1999. Mentoring semogenesis: 'Genre-based' literacy pedagogy. In: CHRISTIE, F. (ed.) Pedagogy and the Shaping of Consciousness: Linguistic and Social Processes. London: Continuum.

MARTIN, J. \& ROSE, D. 2007. Interacting with text: The role of dialogue in learning to read and write. Foreign Languages in China, 4, 66-80.

MATHER, N. \& LAND, S. 2014. Exploring educators' understanding of developing learners' reading skills and their readiness to implement CAPS. Journal for Language Teaching, 48, 199-215.

MKHIZE, D. 2013. The nested contexts of language use and literacy learning in a South African fourth grade class: Understanding the dynamics of language and literacy practices. Doctoral Dissertation, University of Illinois at Urbana-Champaign.

MUDZIELWANA, N. 2012. Teaching reading comprehension to grade 3 Tshivenda-speaking learners. Unpublished Doctoral Dissertation, University of Pretoria.

NAZARYAN, A. 2014. The fallacy of 'Balanced Literacy.'. The New York Times, 7 July. 
NEHAL, M. 2013. A study of reading assessment in the Grade 4 classrooms. Unpublished Masters Dissertation, University of KwaZulu Natal.

NEMOURS. 2017. Let's do it again . . . and again! Why is repetition important to learning? [Online]. Available: http://www.readingbrightstart.org/articles-for-parents/lets-repetitionimportant-learning/ [Accessed 24 April 2017].

NGEMA, M. 2011. Outcomes-based assessment of reading of isiZulu as home language in Grade 3. Unpublished Doctoral Thesis. UNISA.

NKOSI, Z. 2011. An exploration into the pedagogy of teaching reading in selected foundation phase isiZulu home language classes in Umlazi schools. University of KwaZulu-Natal.

PHONIC BOOKS LTD. 2011. What are non-words and why they should be part of the Y1 Phonics Check. Approaches to teaching reading: Synthetic phonics. [Online]. Available: https://www.phonicbooks.co.uk/2011/11/21/what-are-non-words-and-why-they-shouldbe-part-of-the-y1-phonic-check/ [Accessed 17 August 2018].

PLÜDDEMANN, P. 2015. Unlocking the grid: Language-in-education policy realisation in postApartheid South Africa. Language and Education, 29, 186-199.

POLETTE, K. 2005. Read \& write it out loud!: Guided oral literacy strategies, Pearson.

PRETORIUS, E. 2002. Reading and applied linguistics - a deafening silence? Southern African Linguistics and Applied Language Studies, 20, 93-103.

PRETORIUS, E. 2015. Failure to launch: Matching language policy with literacy accomplishment in South African schools. International Journal of the Sociology of Language, 2015, 47-76.

PRETORIUS, E., JACKSON, M., MCKAY, V., MURRAY, S. \& SPAULL, N. 2016. Teaching reading (and writing) in the Foundation Phase: A concept note. RESEP. ZENEX Foundation.

PRETORIUS, E. \& KLAPWIJK, N. 2016. Reading comprehension in South African schools: Are teachers getting it, and getting it right? Per Linguam: a Journal of Language Learning, 32, 1-20.

PRETORIUS, E. \& MAMPURU, D. 2007. Playing football without a ball: language, reading and academic performance in a high-poverty school. Journal of Research in Reading, 30, 3858.

RAMADIRO, B. 2014. Reading in two languages: Evidence from miscue analysis. South African Journal of Childhood Education, 2, 74-93.

REED, D. 2012. Why each spelling? •Why selling instruction matters• A checklist for evaluating a spelling program• Tables of common core state standards linked to spelling. Portsmouth, N.H.: RMC Research Corporation, Center on Instruction.

REEVES, C. \& MULLER, J. 2005. Picking up the pace: variation in the structure and organization of learning school mathematics. Journal of Education, 37, 97-125.

RESCHLY, A., BUSCH, T., BETTS, J., DENO, S. \& LONG, J. 2009. Curriculum-based measurement oral reading as an indicator of reading achievement: A meta-analysis of the correlational evidence. Journal of School Psychology, 47, 427-469.

REUTZEL, D. \& JUTH, S. 2017. Supporting the development of silent reading fluency: An evidence-based framework for the intermediate grades (3-6). International Electronic Journal of Elementary Education, 7, 27-46.

RICHARDS, J. \& RODGERS, T. 2014. Approaches and methods in language teaching, Cambridge, Cambridge university press. 
ROSE, D. 2005. Democratising the classroom: A literacy pedagogy for the new generation. Journal of Education, 37, 131-167.

ROSE, D. 2015. Genre, knowledge and pedagogy in the Sydney School. In: ARTEMEVA, N. \& FREEDMAN, A. (eds.) Trends and Traditions in Genre Studies. Alberta, Canada: Inkshed.

ROSE, D. 2018. Pedagogic register analysis: mapping choices in teaching and learning. Functional Linguistics, 5, 3.

ROSE, D. \& MARTIN, J. 2012. Learning to Write, Reading to Learn: Genre, knowledge and pedagogy in the Sydney School, London, Equinox.

SCHULMAN, L. 1987. Knowledge and teaching: Foundations of the new reform. Harvard Educational Review, 57, 1-21.

SKINNER, B. 1954. The science of learning and the art of teaching. Harvard Educational Review, 24, 86-97.

SPADA, N. \& FRÖHLICH, M. 1995. COLT--Communicative Orientation of Language Teaching Observation Scheme: Coding conventions and applications, Sydney, National Centre for English Language Teaching and Research.

STANLEY, C., PETSCHER, Y. \& CATTS, H. 2018. A longitudinal investigation of direct and indirect links between reading skills in kindergarten and reading comprehension in tenth grade. Reading and Writing, 31, 133-153.

STEINKE, K. 2012. The Effects of the Learn to Read: Reading to Learn Approach on the Academic Literacy Performance of Students in the BCOM4 English Language and Development Programme. Unpublished Masters Dissertation, University of KwaZulu Natal.

STRANGMAN, N., HALL, T. \& MEYER, A. 2010. Background knowledge instruction and the implications for UDL implementation [Online]. Wakefield, MA: National Center on Accessing the General Curriculum. Available: http://aem.cast.org/about/publications/2004/ncac-background-knowledge-udl.html [Accessed 17 August 2018].

TAYLOR, N. 2002. Accountability and support: Improving public schooling in South Africa: $a$ systemic framework [Online]. Jet Education Services. Available: http://jet.org.za/publications/research/Taylor_Accountability\%20and\%20support\%20Tay lor\%20DoE\%202002.pdf [Accessed 23 September 2015].

TAYLOR, S., CILLIERS, J. \& PRINSLOO, C. 2017. The Early Grade Reading Study: Impact evaluation after two years of interventions [Online]. Available: https://static1.squarespace.com/static/5ad0c33a620b85e4b3940685/t/5b212e081ae6cfe4e 04e2055/1528901172519/Grade+2+Report+12+Oct+2017.pdf [Accessed 4 April 2019].

TEDDLIE, C. \& TASHAKKORI, A. 2009. Foundations of mixed methods research: Integrating quantitative and qualitative approaches in the social and behavioral sciences, Thousand Oaks, C.A., Sage.

TOUGH, J. 1977. Talking and Learning, London, Ward Lock Educational.

VAN STADEN, S. \& ZIMMERMAN, L. 2017. Evidence from the Progress in International Reading Literacy Study (PIRLS) and how teachers and their practice can benefit. In: V., S., R., B. \& S., H. (eds.) Monitoring the Quality of Education in Schools. Rotterdam: SensePublishers.

VANDEYAR, S. \& KILLEN, R. 2003. Has curriculum reform in South Africa really changed assessment practices, and what promise does the revised National Curriculum Statement

Per Linguam 2019 35(3):29-58

http://dx.doi.org/10.5785/35-3-806 
hold? Perspectives in Education: Assessment of Change in Education: Special Issue 1, $21,119-134$.

VENTER, A. 2012. 'n Leesgeletterdheidsprofiel van Graad 3-leerders. Unpublished M.A. Dissertation. North West University.

VERBEEK, D. 2010. Teaching Reading for Meaning? A case study of the initial teaching of reading in a mainstream South African School. Unpublished Doctoral Thesis, University of KwaZulu Natal.

VYGOTSKY, L. 1978. Mind in Society: The Development of Higher Psychological Processes, Cambridge, M.A., Harvard.

WANG, Z., SABATINI, J., O'REILlY, T. \& WEEKS, J. 2018. Decoding and reading comprehension: A test of the decoding threshold hypothesis. Journal of Educational Psychology, 1-53.

WEAVER, R. \& QI, J. 2005. Classroom organization and participation: College students' perceptions. The Journal of Higher Education, 76, 570-601.

WILDSMITH-CROMARTY, R. 1997. Thinking through language: Classroom communication, Swaziland, McMillan Boleswa.

WILDSMITH-CROMARTY, R. 2012. Reflections on a research initiative aimed at enhancing the role of African languages in education in South Africa. Journal for Language Teaching, 46, 157-170.

WILDSMITH, R. 1992. Teacher attitudes and practices: A correlational study. Unpublished PhD Thesis. University of London.

XIE, X. 2017. The influence of schema theory on foreign language reading comprehension. The English Teacher, 34, 67-75.

YANG, L. \& WILSON, K. 2006. Second language classroom reading: A social constructivist approach. The Reading Matrix, 6, 364-372.

YIN, R. 2013. Case study research: Design and methods, Thousand Oaks, C.A., Sage publications.

YUSOFF, W. \& SEMAN, S. 2018. Teachers' knowledge of higher order thinking and questioning skills: A case study at a primary school in Terengganu, Malaysia. International Journal of Academic Research in Progressive Education and Development, $7,45-63$.

\section{BIOGRAPHICAL NOTES}

Dr Kellie Steinke has a background in Applied Language Studies and is a lecturer in Academic Literacy at the University of Mpumalanga (e-mail: kelle.steinke@ump.ac.za).

Professor Rosemary Wildsmith-Cromarty is a Professor in the School of Human \& Social Sciences in Education at North West University and Profesor Emeritus at the University of KwaZulu Natal (e-mail: Rosemary.Cromarty@nwu.ac.za). 
APPENDICES

APPENDIX A: FORT PART A - PCK \& READING TEACHING

\begin{tabular}{|c|c|c|c|c|c|c|c|c|c|c|c|c|c|c|c|c|c|c|c|c|c|c|c|c|c|c|c|}
\hline : & 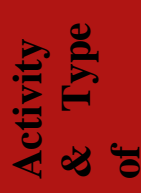 & \multicolumn{5}{|c|}{ Participant Organisation } & \multicolumn{19}{|c|}{ Reading Teaching } & 卷 & $\begin{array}{l}\infty \\
\infty\end{array}$ \\
\hline & & Class & \multicolumn{2}{|l|}{ Group } & \multicolumn{2}{|c|}{ Individual } & \multicolumn{10}{|c|}{ Modality } & \multicolumn{4}{|c|}{ Decoding } & \multicolumn{5}{|c|}{ Comprehension } & & \\
\hline & & & & & & & \multicolumn{5}{|c|}{ Focus on Integrated Skills } & \multicolumn{2}{|c|}{$\begin{array}{l}\text { Silent } \\
\text { Reading }\end{array}$} & \multicolumn{3}{|c|}{$\begin{array}{l}\text { Reading Out } \\
\text { Loud }\end{array}$} & & & & & & & & & & & \\
\hline & & 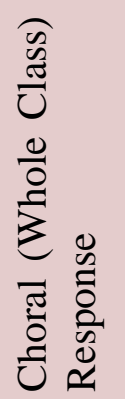 & 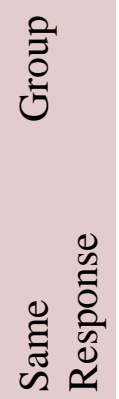 & 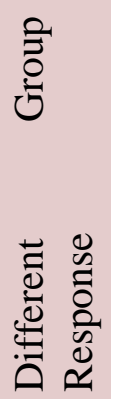 & 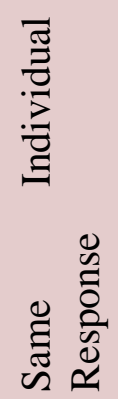 & 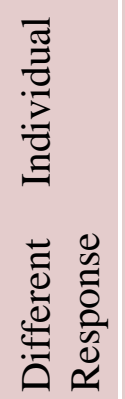 & $\begin{array}{l}\stackrel{\infty}{\Xi} \\
\stackrel{\Xi}{\Xi} \\
\stackrel{\Xi}{\Xi}\end{array}$ & .0 & 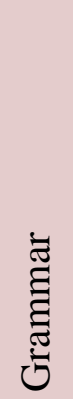 & $\begin{array}{l}\vec{z} \\
\frac{\vec{z}}{3} \\
\frac{0}{0} \\
0 \\
>\end{array}$ & 骂 & 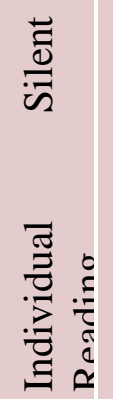 & 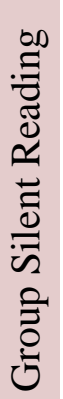 & 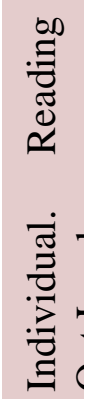 & 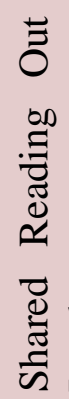 & 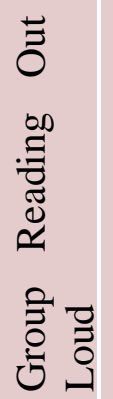 & 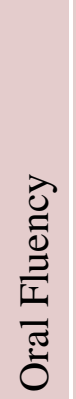 & 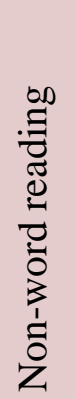 & 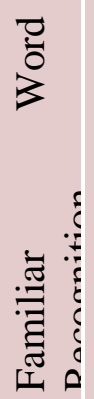 & 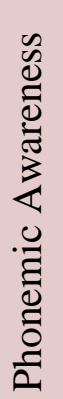 & 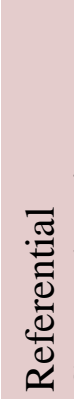 & 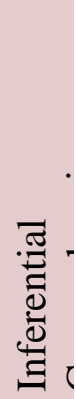 & 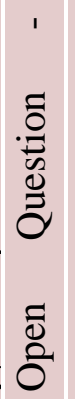 & 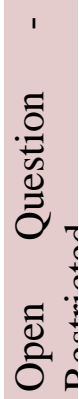 & 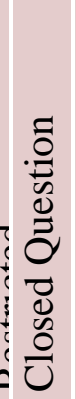 & 吕 & $\frac{3}{2}$ \\
\hline
\end{tabular}

APPENDIX A: FORT PART A - MANAGEMENT 


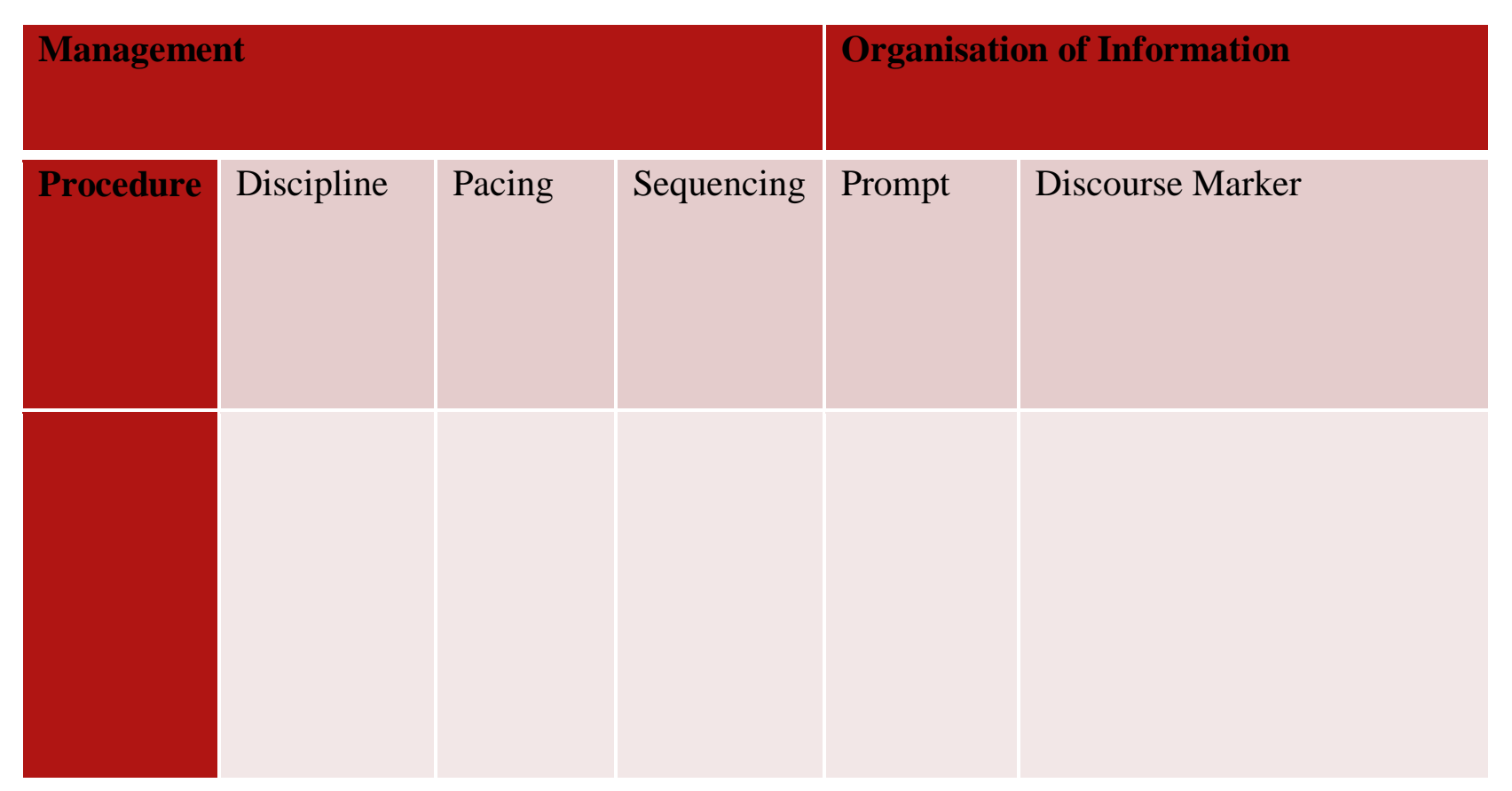

Per Linguam 2019 35(3):29-58

http://dx.doi.org/10.5785/35-3-806 
APPENDIX A: FORT PART B - TEACHER-TO-LEARNER INTERACTION

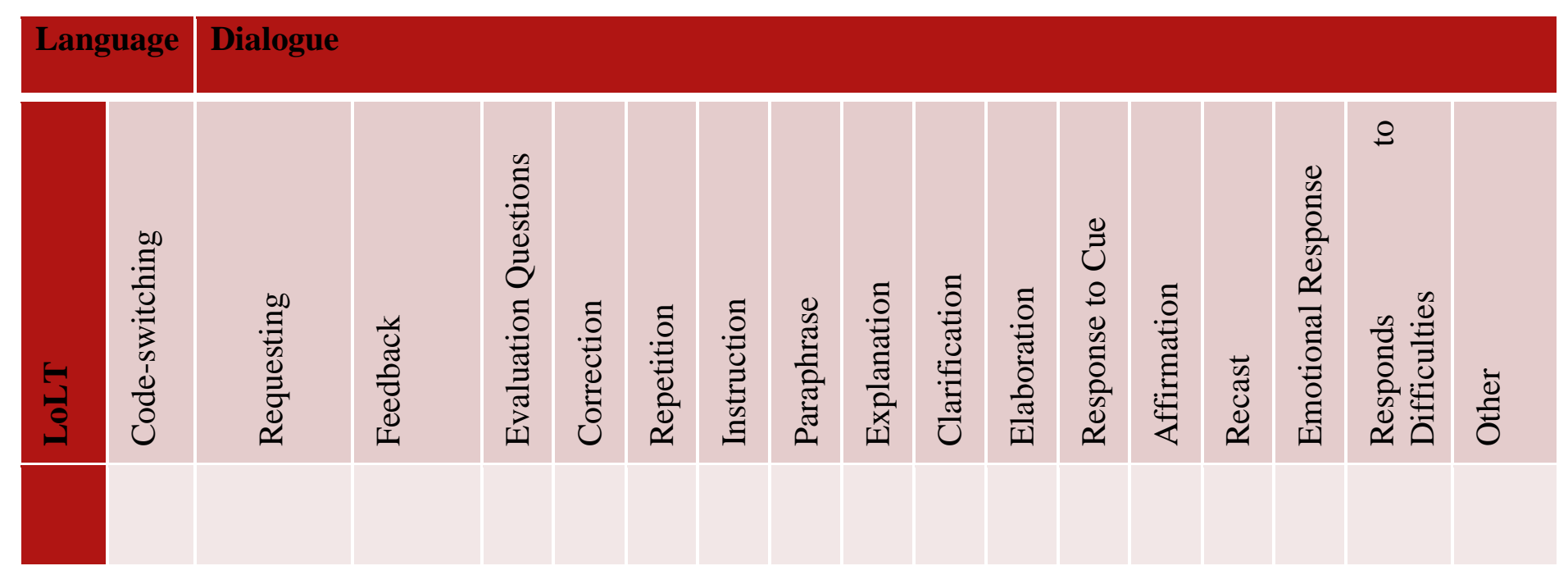


APPENDIX A: FORT PART B - LEARNER-TO-TEACHER INTERACTION

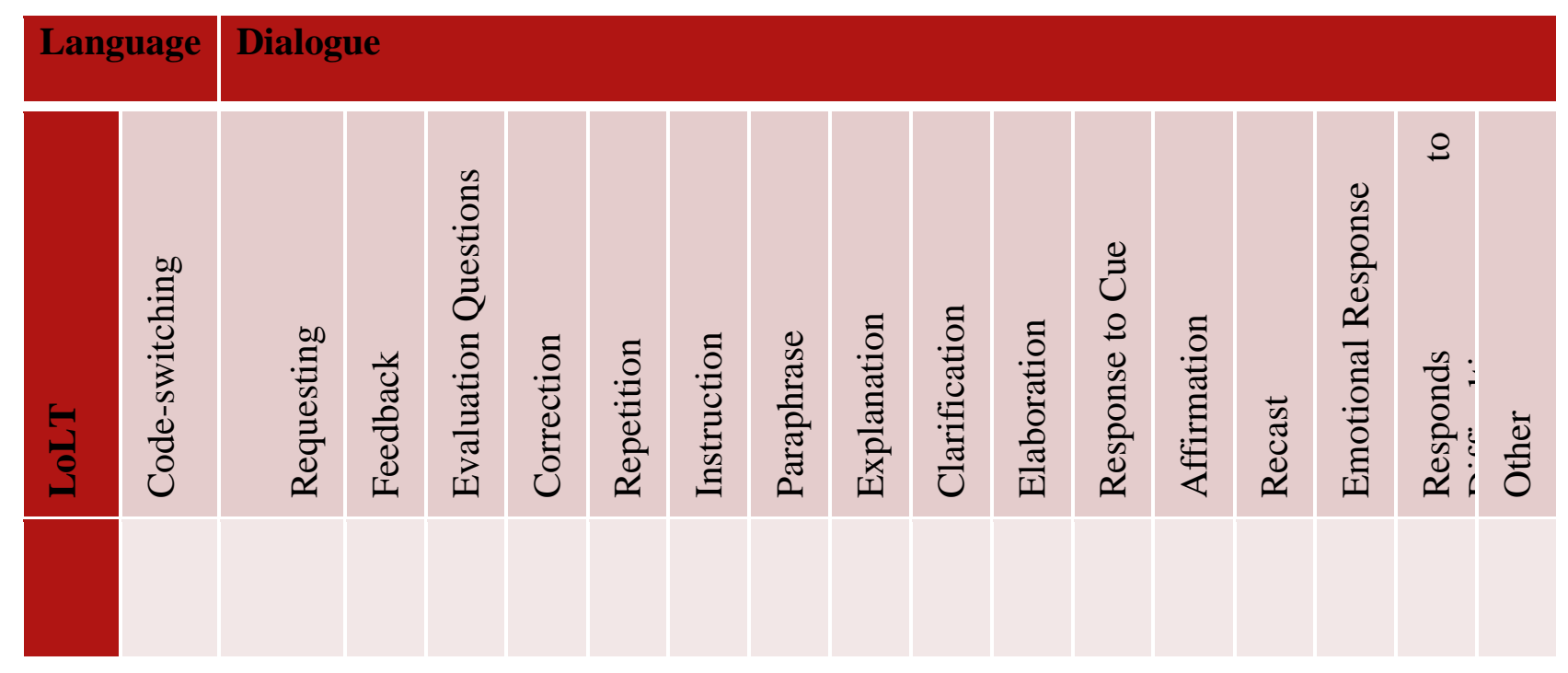




\section{A. SCHOOL DETAILS}

1. School MOI:

2. What grade/s do you teach?

3. How many students are there currently in your class?

4. What is the age range of the learners in each class?

B. PERSONAL DETAILS

5. How many years' teaching experience do you have?

6. What is your mother tongue?

C. PERSONAL DEVELOPMENT

7. How do you feel your qualification helps you in your teaching? Are there ways in which you think it could have been improved?

8. Challenges in teaching?

9. How effective do you believe your own methods are in teaching reading?

D. READING TEACHING

10. What difficulties with reading do your learners experience in the language of learning and teaching?

11. How much support do you feel caregivers/parents provide to the learners and to you?

12. How do you move your learners from decoding to comprehension?

E. ACTIVITIES

13. What do your learners do in class when they learn to read?

F. MATERIALS USED

14. What additional materials to you use to teach reading, other than those prescribed by the curriculum?

G. PACING \& SEQUENCING

15. How often do your learners have a specific time set aside for your reading during class time and how do they respond to this time?

H. PARTICIPANT ORGANISATION

16. What do you believe are the benefits of group work? Why?

I. ACTIVATING KNOWLEDGE

17. How important is it for a teacher to rely on the background knowledge learners acquire outside the classroom? Why?

\section{K. CLASSROOM INTERACTION BETWEEN TEACHER/STUDENT STUDENT/TEACHER}

18. How important do you believe it is to have interaction between teacher and learners and vice-versa in the classroom?

L. LANGUAGE

19. What challenges, if any, do you encounter using English as MOI? 


\begin{tabular}{|c|c|c|}
\hline \multicolumn{2}{|l|}{ Restrictive Pedagogy } & \multirow{2}{*}{$\underset{\text { Emancipatory approaches }}{\longrightarrow}$} \\
\hline Traditional approaches & Communicative approaches & \\
\hline $\begin{array}{l}\text { Behaviourism (Skinner, } \\
\text { 1954). }\end{array}$ & $\begin{array}{l}\text { Freire and Dewey, social } \\
\text { reform, democracy, the } \\
\text { relationship between } \\
\text { knowledge and experience } \\
\text { (Dewey, 1902; Freire, 1972). }\end{array}$ & $\begin{array}{l}\text { Halliday, language as a } \\
\text { functional, social semiotic } \\
\text { (Halliday, 1978; Halliday, } \\
\text { 1994; Halliday, 1996). }\end{array}$ \\
\hline \multirow{4}{*}{$\begin{array}{l}\text { Bloom's Taxonomy of } \\
\text { Educational Objectives } \\
\text { (Bloom \& Krathwohl, 1966; } \\
\text { Krathwohl, 2002). }\end{array}$} & & $\begin{array}{l}\text { Vygotsky, scaffolding and } \\
\text { the ZPD (Vygotsky, 1978). }\end{array}$ \\
\hline & & $\begin{array}{l}\text { Bernstein: Code theory; the } \\
\text { Pedagogic } \\
\text { Classification and Fevice; } \\
\text { (Bernstein, 1990; Bernstein, } \\
\text { 1999). }\end{array}$ \\
\hline & & $\begin{array}{l}\text { Habermas (Habermas, 1989): } \\
\text { critical action theory. }\end{array}$ \\
\hline & & $\begin{array}{l}\text { Martin \& Rose: Genre and } \\
\text { R2L approaches - explicit } \\
\text { teaching of reading and } \\
\text { writing via scaffolding } \\
\text { (Martin, 1999; Martin \& } \\
\text { Rose, 2005; Rose \& Martin, } \\
\text { 2012). }\end{array}$ \\
\hline Rote learning & Natural approaches & $\begin{array}{l}\text { Both deductive and inductive } \\
\text { reasoning are necessary } \\
\text { (Bowers \& Kirby, 2010; } \\
\text { Cumming \& Elkins, 1999) }\end{array}$ \\
\hline Banking & Learner centered & $\begin{array}{l}\text { Learners bring their own } \\
\text { experiences } \begin{array}{r}\text { into the } \\
\text { classroom }\end{array} \text { environment } \\
\text { (Rothery, 1996). }\end{array}$ \\
\hline $\begin{array}{l}\text { Focus on discipline and } \\
\text { teacher authority }\end{array}$ & $\begin{array}{l}\text { Group work; learner } \\
\text { construes meaning through } \\
\text { experience; teacher is the } \\
\text { 'sage on the side'. }\end{array}$ & $\begin{array}{l}\text { Guidance of teacher as well } \\
\text { as peers, are necessary in } \\
\text { order for the learner to reach } \\
\text { the ZPD (Vygotsky, 1978). }\end{array}$ \\
\hline Errors seen as 'wrong' & $\begin{array}{l}\text { Errors can facilitate the } \\
\text { learning process }\end{array}$ & $\begin{array}{l}\text { Some error correction } \\
\text { necessary, depending on } \\
\text { context (Bromley, 2011). }\end{array}$ \\
\hline framing & Weak classification and & Utilises both, depending on \\
\hline
\end{tabular}

Per Linguam 2019 35(3):29-58

http://dx.doi.org/10.5785/35-3-806 


\begin{tabular}{|l|l|l|}
\hline classification & framing & context (Bernstein, 1990). \\
\hline $\begin{array}{l}\text { Bottom-up approach } \\
\text { decoding }\end{array}$ & $\begin{array}{l}\text { Top-down approach } \\
\text { comprehension }\end{array}$ & $\begin{array}{l}\text { Utilises both bottom-up and } \\
\text { topdown approaches } \\
\text { (Steinke, 2012) }\end{array}$ \\
\hline Focus on Form & Focus on meaning & $\begin{array}{l}\text { Both are utilised depending } \\
\text { on context (Rose, 2004; } \\
\text { Steinke, 2012). }\end{array}$ \\
\hline
\end{tabular}

